\title{
Ser adulta e pesquisar crianças: explorando possibilidades metodológicas na pesquisa antropológica ${ }^{1}$
}

\author{
Flávia Pires \\ Doutora em Antropologia Social - Museu Nacional/UFRJ
}

\begin{abstract}
RESUMO: Neste artigo, apresento e discuto os vários métodos e técnicas de pesquisa utilizados na confecção de minha tese de doutorado: observação participante, desenhos, redaçôes, filmagem, diários, fotografias, cartas, entrevistas com crianças, programas de rádio. Há um destaque para as redações, os desenhos e a observação participante, na medida em que esses foram os instrumentos mais frutíferos para se trabalhar o tema da relação entre religião e crianças.
\end{abstract}

PALAVRAS-CHAVE: criança, infância, desenho, observação participante, redação.

\section{Introdução}

Este artigo é resultado de uma pesquisa de campo de quase 14 meses (2000-2005), que culminou com a redação de minha tese de doutorado (Pires, 2007). O trabalho de campo foi feito na cidade de Catingueira, localizada no semi-árido nordestino, no estado da Paraíba. A cidade conta com uma população de aproximadamente 5 mil habitantes, distribuídos entre as zonas rural e urbana. Nessa cidade a religiosidade sempre se 
Flávia Pires. Ser adulta e pesquisar crianças...

mostrou um tema pungente, cujas conexões extrapolam as esferas do "religioso". Minha dissertação de mestrado (Pires, 2003), por exemplo, trata da Festa de São Sebastião, padroeiro da cidade, momento no qual o local recebe turistas e se reinventa em tradiçōes e efervescência social sob as bençãos do santo e da igreja católicos. Como os chamados "crentes" e espíritas kardecistas estão presentes nessa festa religiosa, a princípio católica, é um dos desdobramentos da dissertação. No entanto, na tese de doutorado, trabalhei com crianças dos 3 aos 13 anos de idade, adultos e idosos na tentativa de compor um quadro, tão completo quanto possível, sobre o entendimento e a experiência religiosa naquela comunidade. Ao fazê-lo, deparei-me com a existência de seres chamados "mal-assombros", que podem ser em alguma medida intitulados de religiosos, uma vez que mantêm relações privilegiadas com o chamado o "outro mundo", o mundo após a morte.

Para os adultos e idosos, esses mal-assombros são almas de pessoas falecidas. Para as crianças, por sua vez, os mal-assombros são uma larga gama de seres e acontecimentos. Interessante notar que o medo dos malassombros, altamente enfatizado pelos adultos e idosos, não o é pelas crianças. Isso se explica pelo fato de que, para os adultos e principalmente para os idosos, todos os mal-assombros são temíveis, uma vez que existe uma relação, a princípio inquestionável, entre eles e o diabo. Para as crianças, as coisas não se passam dessa maneira. O mal-assombro assusta menos e, quando o faz, a razão não pode ser associada com nenhuma entidade religiosa. Crescer em Catingueira implica, dentre outros, entender que o mal-assombro é assustador por sua associação com o demônio. Ao mesmo tempo, a pessoa vai se tornando católica ou evangélica ou espírita, conforme as experiências que leva a cabo no decorrer desse processo. É interessante ressaltar a importância do parentesco na definição dos mal-assombros e as diferenças na percepção dos mal-assombros de acordo com as diversas religiōes existentes na cidade. 
Revista de Antropologia, São Paulo, USP, 2007, v. 50 No 1.

À luz dessa experiência de pesquisa, este artigo tem como um dos objetivos discutir a questão dos métodos e das técnicas de pesquisa utilizados no estudo de crianças pela antropologia. Pergunto-me em que medida estudar crianças requer métodos e técnicas especiais ou se devemos continuar aplicando os mesmos instrumentos empregados no estudo dos adultos. Além de mapear os métodos e as técnicas utilizados, discuto sobre o lugar do pesquisador adulto na pesquisa com crianças, os esforços para sair dessa posição e os problemas disso resultantes. O presente trabalho se valeu do uso de materiais de pesquisa não convencionais na tradição de estudos antropológicos, a saber, desenhos, redações, filmagem, diários, fotografias, cartas, entrevistas com crianças, programas de rádio. Apesar de não serem inéditas, as técnicas de pesquisa trabalhadas com base nesses materiais foram pouco utilizadas na pesquisa antropológica. Embora tenha sido largamente utilizada, a metodologia de pesquisa não se restringiu à observação participante. Como será visto, o conjunto dos métodos e técnicas aqui descritos e discutidos foi essencial para a elaboração de minha tese de doutorado. No entanto, é necessário desde já advertir o leitor do fato de que, exceto a observação participante e os desenhos conjugados com as redações, as outras técnicas utilizadas têm um caráter complementar e não foram trabalhadas exaustivamente.

\section{Ser adulta e pesquisar crianças}

Como já aludi, a confecção de minha tese de doutorado contou com a aplicação de vários métodos e técnicas de pesquisa. A observação participante foi largamente utilizada, embora não tenha sido o único método de pesquisa a apresentar resultado positivo. Foi feita observação sistemática e regular de missas, cultos e reuniões espíritas, assim como dos 
Flávia Pires. Ser adulta e pesquisar crianças...

serviços religiosos especialmente destinados às crianças. No caso do catolicismo, trata-se do "catecismo" e da reunião da "Infância Missionária". No caso da Assembléia de Deus, trata-se da "escola dominical". E, por fim, da "reunião das crianças" no caso do Centro Espírita. Foram observados também eventos como funerais, enterros, novenas do mês de Maria (maio), procissóes, a festa do padroeiro e a gincana da Infância Missionária.

A relação com as crianças que participaram mais intensamente da pesquisa foi construída ao longo dos anos. Comecei a fazer pesquisa na cidade de Catingueira no ano de 2000, quando a pesquisa não necessariamente focava as crianças. Desde aquele ano, tenho ido à cidade em intervalos variados, computando ao todo quase 14 meses de trabalho de campo. No entanto, a estadia na cidade foi intensificada nos últimos dois anos de pesquisa, 2004 e 2005. De modo geral, meu primeiro mecanismo de inserção social foram visitas aleatórias. Assim que chegava a uma casa, apresentava-me. Muitas vezes, convidavam-me para entrar. Outras vezes ficávamos na varanda ou, na pior das hipóteses, em pé do lado de fora da porta. Conversávamos sobre amenidades e, depois, eu ia embora. Ao final de alguns meses fazendo visitas diárias, muita gente já me conhecia pelo nome. ${ }^{2}$ Com o tempo e as repetidas "palestras" (conversa, bate-papo), passei a ser conhecida íntima de algumas famílias. Estas famílias, que por sua vez tinham crianças, facilitaram as primeiras interaçôes com as mesmas.

Em 2004, quando a pesquisa passou a se concentrar também nas crianças, foi preciso inventar pretextos para que elas se aproximassem de minha casa. Um dia, ensinei um grupinho de meninas a fazer papel reciclado. A notícia espalhou-se rapidamente e, por fim, a procura por aprender a fazer papel reciclado demandou alguns dias de oficinas. Às vezes, lia uma estória; às vezes, inventava estórias; às vezes, pedia que as crianças contassem estórias. Um dia, fiz um bolo para cantar para- 
Revista de Antropologia, São Paulo, USP, 2007, v. 50 No 1.

béns para um aniversariante. Também inventava brincadeiras, dinâmicas e temas de conversa em grupo. Assim feito, logo a casa estava sempre "cheia de menino", como se costuma dizer em Catingueira. Concomitantemente, fui muitas vezes às casas das crianças, mas a opção por convidá-las para a minha casa tem como justificativa o fato de que queria observá-las também longe de suas famílias.

Talvez seja necessário discorrer um pouco sobre a opção de chamar as crianças para desenhar em minha casa. O leitor pode se perguntar o motivo pelo qual eu não priorizei a casa das crianças, o seu ambiente "natural", a fim de levar a cabo a pesquisa. Quero esclarecer que freqüentei as casas das crianças e as observei em interação familiar. No entanto, apostei também na pesquisa com as crianças entre si, longe do olhar disciplinador do adulto. Com isso, resolvi convidá-las para a minha casa, o que se mostrou produtivo. Todavia, Latour (2005) faz consideraçōes interessantes sobre a elaboração do fato científico nas ciências sociais, especialmente a sociologia. Ele afirma que a artificialidade faz parte de qualquer experimento científico, inclusive na antropologia:

Descrever, cifrar, narrar e escrever relatórios finais são atividades tão não naturais, complexas e escrupulosas quanto dissecar moscas de frutas ou mandar um telescópio para o espaço. Se você pensa que os experimentos de Faraday são notadamente artificiais, o que você pensa sobre as expedições etnográficas de Pitt-Rivers? Se você acredita nas invenções de laboratório de lorde Kelvin, o que dizer de Marx compilando notas de fim de página na Biblioteca Britânica, Freud pedindo às pessoas para fazerem associações livres no seu sofá em Vienna, ou Howard Becker tentando aprender a tocar jazz para tomar notas de pesquisa sobre o jazz? (Latour, 2005, p. 136 , tradução minha) $)^{3}$ 
Flávia Pires. Ser adulta e pesquisar crianças...

A presença do pesquisador introduz artificialidade ao contexto pesquisado, o que, embora não seja possível evitar, deve ser assinalado.

As crianças pareciam gostar de ir a minha casa e se alternavam em função do horário da escola e das atividades domésticas pelas quais são responsáveis. Se quisesse ficar sozinha, a única solução era não abrir a porta ou as janelas da casa, fingindo que não estava ou que estava dormindo. ${ }^{4} \mathrm{Lá}$ em casa, as atividades funcionavam assim: em cada período do dia, seja manhã ou tarde, pedia que as crianças fizessem, pelo menos, um desenho ou uma redação. Isso era considerado o "trabalho". Depois disso, as crianças eram liberadas para brincar conforme quisessem no quintal, chamado de "muro", ou dentro de casa. ${ }^{5}$ Dentro de casa, dentre outras brincadeiras, a preferida era abrir um velho jogo de sofá-cama que ficava na sala e pular em cima dele, como se fosse um pula-pula. Todas as crianças, das pequeninas (de 2 e 3 anos) até as de 14 e 15 anos, adoravam pular em cima do sofá. No entanto, as crianças nunca o fizeram sem pedir a minha permissão. Nos momentos em que eu perdia a paciência com a barulheira dentro de casa, minha estratégia era simplesmente pedir para fechar o sofá, o que equivalia a pedir que elas fossem embora. Quando isso acontecia, todos rapidamente paravam de pular e de gritar, fechavam o sofá e ficavam sentados, quietinhos, calados, tristonhos. Então, uma criança chamava a outra: "Lulu, vamos embora". Lulu levantava-se imediatamente e, então, uma avalanche de "vamos embora” levava toda a algazarra, deixando para trás o silêncio (e, é claro, alguma sujeira para ser limpa).

Hoje, retrospectivamente, tenho a impressão de que foi esse sofá a minha maior moeda de troca com as crianças. Elas me davam companhia e desenhos, e recebiam de volta um sofá para pular! O fato é que as crianças não são autorizadas a pular no sofá em suas próprias casas, ${ }^{6} \mathrm{e}$ até as brincadeiras, principalmente dentro de casa, têm certa disciplina a ser seguida. Aos poucos, percebi que as crianças iam para a minha casa, 
sob a desculpa bastante digna de que estavam estudando comigo - o que justificava até negligenciar os afazeres domésticos para brincar livremente, pulando, gritando, correndo e também brigando uns com os outros. Entretanto, não me tinha dado conta de que, talvez, as crianças estivessem extrapolando na gritaria a ponto de incomodar os vizinhos, até que uma de minhas vizinhas comentou com outra, que, por fim, comentou com a cidade inteira que ia denunciar-me para a proprietária do imóvel onde eu morava, sob a acusação de que estava "deixando as crianças destruírem a casa”!

Afora minha chateação com a intolerância da vizinha, o incidente iluminou alguns aspectos sobre o estatuto da criança naquela cidadezinha. Como, por exemplo, que se deve impor limites às crianças. Que os adultos devem estabelecer uma certa distância em relação a elas se querem ser respeitados. Que o respeito aos mais velhos deve ser ensinado e exigido desde cedo. Que a criança deve ficar em silêncio na presença de adultos, principalmente quando os adultos estão conversando. Que, enfim, elas devem servir os adultos porque "o direito" do adulto ultrapassa o da criança. ${ }^{7} \mathrm{O}$ atrito com a vizinha rabugenta vem do fato de que, segundo ela, eu não estava me comportando de acordo com o que é esperado de uma pessoa adulta. De um adulto espera-se que ele não deixe as crianças fazerem muita algazarra ou que, pelo menos, coloque ordem na bagunça quando for preciso. Agindo daquele modo, eu só podia ser considerada uma irresponsável. Conseqüentemente, isso colocava a própria possibilidade de realização da pesquisa em jogo. Precisava contar com a aprovação dos pais das crianças para que eles as deixassem em minha companhia. Para levar a cabo o meu trabalho, de um lado, era preciso aproximar-me das crianças e, até certo ponto, "fazerme um" com elas; de outro, não poderia comportar-me excessivamente como criança, por correr o risco de perder a confiança de seus pais, comprometendo a própria pesquisa. De fato, três meninas, muito assíduas 
Flávia Pires. Ser adulta e Pesquisar crianças...

às atividades em minha casa, repentinamente deixaram de comparecer. Vim a saber mais tarde, por elas mesmas, que a tal vizinha tinha comentado com suas mães sobre as bagunças que vinham fazendo em minha casa, o que resultou na proibição de freqüentá-la.

Do ponto de vista das crianças, eu também não podia ser considerada uma adulta nos termos correntes. Afinal, que tipo de mulher deixa as crianças "destruírem" a casa? Pular no sofá ou gritar dentro de casa não é certo. $\mathrm{E}$ as crianças sabem disso porque insistiam, com a expectativa estampada no rosto, em sempre me perguntar se podiam mesmo abrir o sofá. De fato, quando pulavam no sofá, as crianças não poupavam entusiasmo, gritavam a plenos pulmões, dançavam e cantavam extravagantemente. Era como se soubessem que aquela alegria era daquele tipo proibida, que só pode durar muito pouco. De outro lado, aos olhares infantis, eu também não podia ser considerada uma criança plena, principalmente por dois motivos: (1) eu morava sozinha e (2) os meus pais não estavam por perto. Meu objetivo durante o trabalho de campo era aproximar-me das crianças e, se permitia certas extravagâncias em minha casa, era com vistas a me distinguir dos outros adultos aos olhos infantis. ${ }^{8}$

Como de costume, aos domingos eu ia ao catecismo. O mesmo acontece em uma sala de aula onde se amontoam crianças de 3 a 15 anos de idade. ${ }^{9}$ Minha estratégia era sempre tentar estabelecer certa distância em relação às professoras de religião: as catequistas, a chamada "professorinha” da reunião dominical, e em relação às "meninas" que ajudavam na reunião infantil do Centro Espírita. Na prática, isso se dava, por exemplo, quando, no caminho para o catecismo, preferia a companhia das crianças à das professoras. Da mesma forma, eu tomava partido nas brincadeiras promovidas pelas professoras filiando-me ao grupo das crianças. Minha intenção era que as crianças soubessem que eu não era como as professoras; que, apesar de ser adulta, estava ali para aprender, e não para lhes ensinar religião. Para as professoras, por sua vez, ter por perto 
um adulto que não age como tal - dado que elas estavam acostumadas a estarem sozinhas com as crianças - é uma situação, no mínimo, embaraçante. Por isso, elas constantemente tentavam envolver-me na direção da reunião. Às vezes, não era fácil recusar certos pedidos das professoras. Elas pediam-me para fazer a oração, pediam para ler a historinha ou a Bíblia e, às vezes, pediam por socorro no quesito disciplina. Eu recusava, sempre recusava, mas, uma vez ou outra, elas acabavam por me passar a palavra, o que soava como inquisiçôes do tipo: "O que tu acha disso, Flávia?”. Normalmente, não sabia o que responder, provavelmente gaguejava e, por fim, conseguia escapar, dizendo algo não muito consistente. Às vezes - o que era ainda pior - a professora me passava o controle de uma classe; por exemplo, no caso da ausência de uma das professoras. Essas situações não eram produtivas do ponto de vista da pesquisa, na medida em que me colocavam em situação de autoridade em relação às crianças, demolindo meu objetivo de me aproximar delas. Se as crianças me vissem como um aprendiz e não como uma professora que sabe todas as respostas e ensina, seria mais fácil desencadear uma relação de cumplicidade e confiança, o que tornaria possível a pesquisa.

Uma vez, no catecismo, depois de lerem uma história bíblica, as professoras iam começar a ditar as perguntas que deveriam ser respondidas a fim de avaliar o nível de compreensão da passagem bíblica lida. Todas as crianças abriram seus cadernos e ficaram a postos, com o lápis na mão, para escrever as questôes. Uma criança, percebendo que eu não trouxera caderno nem lápis para anotar as questôes, perguntou-me se queria emprestados uma folha do seu caderninho e um lápis para fazer o meu exercício. Nesse momento, para aquela criança, eu era apenas mais uma estudante que tinha por obrigação copiar o ditado e que estava em apuros por ter esquecido de trazer os materiais. Nesse mesmo dia, as professoras pediram que as crianças se dividissem em grupos para uma tarefa que fariam em casa. Um menino e uma menina saíram de seus assentos 
Flávia Pires. Ser adulta e pesquisar crianças...

e vieram correndo me perguntar se eu já tinha grupo, caso contrário, eles convidavam-me para entrar no seu grupo. Nesse dia, voltei para casa satisfeita com o resultado de minha inserção, pelo menos no catecismo.

É imprescindível ressaltar que meu intento não era "tornar-me nativa"10 mas, sim, ser assimilada pelas crianças como uma adulta diferente. Uma adulta que interage com elas, seja brincando, seja conversando, seja discutindo. Como já foi enfatizado, em Catingueira, o estatuto das crianças e o dos adultos são tidos como inteiramente distintos. Os adultos não interagem demasiadamente com as crianças. As crianças não escutam conversa de adulto, não participam em ambientes de adultos. Seria considerado desrespeitoso se uma criança ousasse discutir a opinião de seus pais ou responsáveis. Parece que as crianças e os adultos, em grande medida, são vistos como ontologicamente diferentes, habitantes de mundos que não devem correr o risco de se misturar. Acredita-se que criança que convive excessivamente com adultos aprende o que não deve. De outro lado, um adulto que interage demasiadamente com as crianças só é tolerado em situaçôes já previstas, como, por exemplo, na escola, no consultório médico ou no cuidado infantil cotidiano que as meninas mais velhas dispensam às crianças. Todavia, para a realização da pesquisa, era preciso ir contra esse modo de interação local entre crianças e adultos. Precisava me aproximar das crianças, a fim de trocar experiências de vida. Precisava ouvir as crianças, suas opiniões sobre o mundo, sobre religião, sobre os fatos do cotidiano.

É preciso esclarecer que meu interesse pelas crianças parece não ter levantado suspeita - o que poderia ter sido diferente em outras cidades. Isso se deve parcialmente ao fato de que é considerado normal que as mulheres solteiras passem tempo com as crianças, cuidando delas, ensinando os deveres escolares ou simplesmente "matando o tempo". No entanto, às vezes, causava impressão o fato de que eu nunca me cansava delas e que estava sempre disposta a recebê-las em minha casa, uma vez 
que o cuidado dispensado às crianças é visto, algumas vezes, como um serviço penoso porque exaustivo. Algumas mães disseram-me que não deixavam a sua criança na rua ou na casa dos outros, mas que a única casa que sua(seu) filha(o) freqüentava era a minha, enfatizando a confiança em minha pessoa. Em Catingueira, a criança não deve ficar na casa dos outros ou na rua por muito tempo por estar sujeita a aprender o que não deve. Uma mãe, cujo filho fica muito tempo nas casas alheias ou na rua, pode ser taxada de displicente e culpada caso essa criança incorra em erro.

A solução para esse impasse, de ser adulto e pesquisar criança de uma perspectiva antropológica, deve ser buscada no campo, de acordo com cada caso estudado. Corsaro (2003), por exemplo, descreve que sua imperícia no domínio da língua italiana facilitou a interação com as crianças em uma escola na Itália. Ele era visto, pelos alunos, como uma criancinha, que ainda estava balbuciando as primeiras palavras. Isso acabou por inverter a relação costumeira: as crianças empenharam-se em ensinar (o idioma) ao adulto. $\mathrm{Eu}$, de certa forma, realizei meu intento na medida em que falhei como mulher adulta - deixando as crianças "destruírem a casa" onde morava - e, ao mesmo tempo, expus-me às atividades tipicamente infantis, como as brincadeiras. Não acredito que as crianças tenham me visto como uma criança. Mas acredito que o fato de eu ser adulta e elas serem crianças deixou de ser um imperativo negativo para a relação. Mais do que uma adulta, eu estava sentada na carteira ao lado, ouvindo e prestando atenção ao catecismo. Enfim, a atividade em que estávamos imersas suplantou o fato da nossa diferença de idade. ${ }^{11}$

Apesar de ter sido quase sempre bem-vinda às rodas infantis, lembro-me de que as crianças, às vezes, não permitiam minha participação nas atividades e conversas. Quando eu era criança, algumas meninas em meu colégio interagiam entre si usando a língua do "pê"12 - língua na 
Flávia Pires. Ser adulta e pesquisar crianças...

qual eu, sofregamente, nunca consegui ser fluente. Em Catingueira, curiosamente, as crianças utilizavam o mesmo recurso da língua do "pê" para me excluir de certas conversações. O interessante é que elas o faziam deliberadamente, na minha vista, como se quisessem tornar explícito o abismo que nos distinguia. Dessa forma, temos mais um motivo para acreditar que elas não me viam como criança. Parece-me plausível afirmar que os mundos do pesquisador enquanto um adulto e o do nativo enquanto criança são comunicáveis. Mas nem sempre é o caso.

\section{Desenhos e redações: condução, considerações e resultados}

Como afirmei, os desenhos já foram usados em outras pesquisas antropológicas. Mead e Bateson (1942) coletaram em Bali mais de 1.200 desenhos, entre os anos de 1937 e 1939, feitos por adultos em sua maioria e que são acrescidos de um relato sobre os mesmos (Geertz, 1995). ${ }^{13}$ $\mathrm{Na}$ pesquisa por mim empreendida, os desenhos foram largamente utilizados como material de pesquisa complementar à participante. Ao desenhar sobre um tema proposto, as crianças colocam no papel o que lhes é mais evidente. Nesse sentido, o desenho é um material de pesquisa interessante para captar justamente aquilo que primeiro vem à cabeça, aquilo que é mais óbvio para a criança. Porém, quando combinado com a observação participante, é que os dois instrumentos potencializam a sua utilidade. Os desenhos podem funcionar como um guia para a observação participante. Com os desenhos à mão, é possível direcionar o olhar para a realidade de acordo com os tópicos levantados pela população estudada. De outro lado, a observação participante dá corpo ou refuta as sugestôes que os desenhos engendram. ${ }^{14}$ 
Revista de Antropologia, São Paulo, USP, 2007, v. 50 No 1.

Foram feitos três tipos de desenhos: (1) livres, (2) temáticos e (3) temáticos controlados. Chamo de desenho livre aqueles sem tema definido a priori, nos quais as crianças decidiam por elas mesmas, ora individualmente ora coletivamente, o que desenhariam. Muitas vezes, elas mesmas tomavam a iniciativa de pedir para desenhar; outras vezes, eu sugeria. ${ }^{15}$ Esse tipo de desenho é interessante principalmente em um primeiro momento da pesquisa porque, baseado nele, pode-se melhor definir os temas que devem ser aprofundados. Fizemos um total de 172 desenhos livres, cujos temas mais ressaltados foram: (1) elementos da natureza, tanto como tema principal do desenho quanto coadjuvante, decorando a folha de papel; (2) casas, que são desenhadas sempre com portas e janelas. Abaixo, veja a lista completa dos elementos mais desenhados nos desenhos livres:

$\begin{array}{lr}\text { Elementos da natureza } & 64 \\ \text { Casa } & 32 \\ \text { Gente } & 24 \\ \text { Mal-assombro } & 17 \\ \text { Religiosos }^{16} & 12 \\ \text { Outros } & 10 \\ \text { Conjugados (casa, natureza e outros) } & 5 \\ \text { Festa de São João } & 3 \\ \text { Carro } & 3\end{array}$

A classificação dos desenhos parece-me ser uma questão a ser discutida. As categorias acima utilizadas foram idealizadas pela pesquisadora para dar conta de um sem-número de elementos desenhados. Em última instância, o que foi considerado, por exemplo, "religioso" ou "gente" foi decidido pela pesquisadora. No entanto, todas as crianças descreveram seus desenhos, o que orientou a classificação dos mesmos. Para 
Flávia Pires. Ser adulta e pesquisar crianças...

exemplificar mais detalhadamente, no caso em que a criança descreveu seu desenho como "a minha irmã", esse desenho acabou sendo contabilizado na categoria "gente". Particularmente, a categorização os "elementos da natureza” pode levantar algumas dúvidas. É importante ressaltar que, por exemplo, a Serra da Catingueira não é tida exclusivamente como "a natureza", senão pelos forasteiros das grandes cidades, que ocasionalmente aportam em Catingueira para desfrutar da subida da serra. Para as pessoas que moram na cidade, a serra não existe apenas em função do ecoturismo. A Serra da Catingueira enfeita a cidade, hospeda os cruzeiros onde se pagam promessas e abriga os mal-assombros Maria Fulorzinha e o Carneiro de Ouro. Além disso, ela serve de pasto para o gado, contém a Furna (caverna) e a Cachoeira da Mãe Luzia, e serve de moradia para famílias, dentre outros. Por isso, não poderíamos afirmar que, para as crianças, a serra é apenas parte do mundo da "natureza" embora, no caso dos desenhos livres, a serra tenha sido categorizada como elemento da natureza, assim como as árvores, os pássaros e as flores. Por tudo isso, o esforço de classificação dos desenhos é útil como o primeiro passo na direção de uma análise mais completa, mas não deve ser tomado como suficiente em si mesmo.

Em uma segunda etapa da pesquisa, pode-se propor desenhos com temas específicos, baseando-se nas dicas que as próprias crianças apresentam nos desenhos livres. Propus temas os mais variados, como "A minha família", "O que eu mais gosto/odeio na vida", "A minha futura família", "O meu maior sonho", "Um homem mau morreu, para onde ele foi?”, "Em quem você votaria para prefeito?”, entre inúmeros outros que perfazem um total de 241 desenhos. ${ }^{17}$ Tanto os desenhos livres quanto os desenhos temáticos foram todos feitos em casa, no ambiente descrito anteriormente. Aqui também é útil ressaltar que os temas dos desenhos, embora discutidos com as crianças, foram propostos por mim, 
Revista de Antropologia, São Paulo, USP, 2007, v. 50 No 1.

de acordo com os interesses da pesquisa, e não podem ser confundidos com o espelho do real da vida infantil.

Depois dos desenhos livres e dos desenhos temáticos, resolvi aprofundar dois temas específicos que iam ao encontro do tema da pesquisa por mim realizada e que, ao mesmo tempo, eram recorrentes no imaginário infantil de Catingueira. $\mathrm{O}$ objetivo era recolher uma amostra abrangente de desenhos em relação a cada faixa etária a ser pesquisada. Elaborei uma amostra que cobre crianças dos 3 aos 13 anos de idade em relação aos temas "A minha religião" e "O mal-assombro". Recolhi pelo menos 20 desenhos de cada faixa etária em relação aos dois temas apresentados, o que perfaz um total de 250 desenhos do tema "A minha religião" e 314 desenhos do tema "O mal-assombro". Esse tipo de desenho chamei de "temático controlado". Pela maior quantidade de desenhos, já se percebe a predileção das crianças pelo tema do mal-assombro. Quando solicitadas que desenhassem, escrevessem ou falassem sobre a religião, as crianças tendiam a relutar diante da proposta da pesquisadora, afirmando sua inaptidão ou seu desgosto pela tarefa. Além disso, a escolha do tema de desenho "A minha religião" parece ter tido repercussões importantes nos desenhos das crianças - a discussão dessas repercussões está trabalhada em Pires (2007, pp.14-21, 154-78).

A aplicação dos desenhos temáticos controlados ocorreu nas duas escolas na cidade, durante os meses de março a maio de 2004, sendo complementada e finalizada durante o mês de julho de 2005. A escolha por aplicar os desenhos nas escolas deu-se pela comodidade de se encontrar o número de crianças necessário (20), já estrategicamente divididas em grupos etários. Como não foi possível encontrar as 20 crianças na faixa etária dos 3 anos de idade freqüentando escolas, fui ter com elas em suas casas, tendo o cuidado de controlar ao máximo as possíveis interferências familiares na execução do desenho. Dessa forma, apenas 
Flávia Pires. Ser adulta e pesquisar crianças...

nesta última faixa etária, os desenhos não foram coletados em sua integralidade no ambiente escolar.

A cidade conta com duas escolas, uma gerida pela municipalidade e outra pelo estado da Paraíba. Minha primeira providência foi procurar a diretora da escola do estado em sua casa. Apresentei-me, falei da pesquisa que estava conduzindo e pedi sua autorização para aplicar os desenhos nos próximos dias. Ela consentiu prontamente. Fui ter com a diretora da escola do município (que mora em Patos-PB) ${ }^{18}$ na própria escola. Na parte da manhã, diante de sua ausência, uma auxiliar me autorizou a começar a pesquisa. Pela tarde, pude conversar com a diretora, que não apresentou qualquer empecilho à condução de meu trabalho. Também não encontrei qualquer tipo de oposição à pesquisa por parte dos funcionários das escolas; pelo contrário, geralmente todos ficaram entusiasmados em poder contribuir. $\mathrm{O}$ mesmo aconteceu com as professoras e os professores. Uma única professora aproveitou o tempo em que eu estava na sala para descansar, deixando-me sozinha com as crianças. As outras professoras, a grande maioria, no entanto, permaneceram dentro da sala, auxiliando as crianças e dando suporte no quesito disciplina. Algumas professoras acabaram por influenciar o que seria desenhado ao dar dicas sobre o que e como desenhar dentro do tema proposto. Mas isso não resultou em grande prejuízo na medida em que as crianças interpretam a fala do adulto e acabam por fazer seu próprio desenho. No entanto, algumas professoras chegaram a pegar na mão das crianças para ajudar a desenhar o que os pequenos diziam não serem capazes. Embora sob meus protestos, uma única vez uma professora desenhou no lugar da criança. O tempo gasto em cada sala de aula variou entre 30 minutos e 1 hora.

Geralmente, a diretora ou sua auxiliar ia comigo até a porta da sala de aula para me apresentar à professora (ou ao professor) e aos alunos. Depois da breve apresentação, eu saudava a professora (ou o professor) 
Revista de Antropologia, São Paulo, USP, 2007, v. 50 No 1.

e os alunos, e explicava que estava conduzindo uma pesquisa para meu doutorado, acentuando que precisava de sua contribuição. Em seguida, apresentava o tema a ser desenhado e dava as instruções. Às crianças não alfabetizadas era pedido que desenhassem e, depois, a sua interpretação do desenho seria registrada. Quando se tratava de crianças em fase de alfabetização, a instrução era que desenhassem e escrevessem alguma coisa sobre seu desenho (uma frase, pelo menos). Já no caso de crianças alfabetizadas, a instrução era que fizessem um desenho e uma redação sobre o tema. E, no caso de crianças acima de 13 anos, a instrução era que fizessem uma redação e, se quisessem, complementarmente podiam desenhar (geralmente, as meninas o fizeram, e os meninos não). Dessa forma, os materiais de pesquisa produzidos são desenhos, redações e desenhos conjugados com redaçóes.

$\mathrm{Na}$ sétima e na oitava séries do ensino fundamental, devido às altas taxas de repetência, deparei-me com muitos alunos adultos. Somente nesse momento observei resistência deliberada à pesquisa - geralmente por parte dos adolescentes do sexo masculino. Atitudes "engraçadinhas" foram observadas, por exemplo, quando um dos rapazinhos, que deveria escrever sobre religião, perguntou-me "se eu fizer a redação, eu ganho uma passagem para o céu?", provocando uma gargalhada geral na classe. Alguns outros entregaram a folha em branco, e outros copiaram literalmente o que um colega tinha escrito. Não sei se de brincadeira ou não, mas um menino de 16 anos (E.F. 16 M. 3) ${ }^{19}$ escreveu uma estória de mal-assombro na qual, segundo ele, o monstrengo parecia-se comigo! ${ }^{20}$ No entanto, esse viés da pesquisa acabou sendo útil, na medida em que acumulei alguns desenhos que podem favorecer uma comparação entre a visão dos adultos, a dos adolescentes e a das crianças por meio do uso da mesma técnica de pesquisa. Todavia, geralmente as crianças responderam com prazer à minha proposta de pesquisa. Algumas delas ressentiram-se do fato de eu não ter "passado" por suas salas. Mesmo 
Flávia Pires. Ser adulta e Pesquisar crianças...

depois de alguns meses de concluída essa etapa da pesquisa, algumas crianças ainda paravam-me na rua para pedir minha presença na sua sala de aula.

Todos os materiais necessários para desenhar e fazer a redação foram providos. Os lápis de colorir e os de cera, folhas de papel em branco e o apontador de lápis (chamado localmente de lapiseira) acabaram por desempenhar um papel importante de incentivo à participação na pesquisa, uma vez que esses elementos tinham bastante apelo entre as crianças. ${ }^{21}$ Pergunto-me se o entusiasmo das crianças com os materiais escolares pode ser entendido como uma particularidade do campo de estudos no qual atuo, uma vez que grande parcela das crianças não tem acesso a eles - a não ser esporadicamente na própria escola. No entanto, Mead (1932) relata que as crianças manus estavam sempre dispostas a desenhar, apesar de não possuírem tradição pictográfica e, conseqüentemente, de o desenho não ser uma atividade à qual as crianças dedicam-se espontaneamente nas horas de lazer ou de estudo. Além disso, Cohn (2006) também afirma que as crianças xikrin gostavam bastante de desenhar.

Como afirmei, quando finalizado um desenho, a criança sempre era incentivada a colocar um título no mesmo e a escrever sobre ele, elaborando o que eu denominei a "estória do desenho". No caso de crianças iletradas, elas eram incentivadas a falar sobre o desenho - de preferência para a pesquisadora, mas, se não fosse possível, também para uma criança maior ou para a professora. Estas últimas, por sua vez, redigiriam a sua reflexão sobre aquele desenho na parte de trás da folha. Os desenhos úteis para a pesquisa antropológica são, sem dúvida, aqueles nos quais as crianças se esmeraram nos comentários. Diferentemente dos psicólogos, os antropólogos não são treinados para inferir qualquer conclusão com base em um desenho. ${ }^{22}$ Em meu caso específico, precisava das crianças para me dizer se uma árvore desenhada era um "mal-assombro" ou a "mangueira do sítio do meu avô". ${ }^{23}$ Para esclarecer este ponto, cito um 
exemplo. Três crianças diferentes desenharam uma cópia de uma imagem de um livro. $\mathrm{O}$ interessante é que cada uma delas interpretou a imagem de maneira diferente, quais sejam: "Santa com o anjinho" (D. 6. M. 6), "Mãe de Deus" (M. 6. F. 5) e "Maria e Jesus" (J. 8. F. 1). Enquanto, para mim, a imagem correspondia a uma quarta interpretação: uma santa da tradição católica que não sou capaz de identificar. Dessa forma, a reflexão da própria criança sobre aquilo que ela mesma desenhou assim como a reação aos desenhos das outras crianças devem ser incentivadas porque são matéria-prima para a pesquisa. Como descrevo em Pires (2007, pp. 73-94), quando Y. 10. F. discorria sobre seu futuro de mulher casada, acentuando que o marido e ela iam trabalhar fora o dia todo, A.J., de 6 anos de idade, que acompanhava a elaboração do desenho, imediatamente perguntou: "E quem vai fazer a comida?". Por outro lado, os desenhos sem título ou sem a "estória do desenho" não puderam ser aproveitados para a análise que se seguiu.

James, Jenks e Prout concordam que a eficácia da técnica do desenho é potencializada na medida em que ele é motivo de discussóes posteriores: "Conversar com as crianças sobre os significados que elas atribuem a seus desenhos ou pedir a elas que escrevam uma estória permite que as crianças se engajem mais produtivamente nas nossas questóes de pesquisa, usando os talentos que elas possuem" (1998, p. 189, tradução minha). Além disso, o desenho mostra-se uma técnica adequada para trabalhar com as crianças, dentre outras coisas, porque, conforme James e Christensen (2000), desenhar é um ato que não requer nenhum skill especial, uma vez que constantemente as crianças desenham por lazer. ${ }^{24}$ Além disso, o desenho está menos sujeito à crítica se comparado ao texto escrito (em relação, por exemplo, à correção gramatical e ortográfica) e, portanto, menos associado às atividades desenvolvidas no ambiente escolar.

No entanto, algumas considerações sobre a aplicação dessa técnica merecem ser elaboradas. As crianças, muito constantemente, copiam o 
Flávia Pires. Ser adulta e pesquisar crianças...

que alguma delas está desenhando. Geralmente, copiam do mais velho, do considerado o mais inteligente ou daquele que sabe desenhar melhor. Nunca interferi no momento em que uma criança estava deliberadamente copiando um desenho da outra. O que eu sempre fazia, no entanto, quando distribuía os papéis e comentava sobre o tema a ser trabalhado naquele dia, era alertar para que elas tentassem não olhar para o que o colega estava desenhando. E, se por acaso olhassem, tentassem inventar algo diferente. Ressaltava também que não existia desenho errado, que todos estavam certos e que eles podiam desenhar o que quisessem. Como incentivo, eu geralmente acrescentava um elogio aos desenhos assim que me fossem entregues. Mead (1932) afirma que, da mesma forma, não interferia na elaboração dos desenhos, a não ser para incentivar as crianças com palavras de encorajamento. ${ }^{25}$

Acredito que eu seria facilmente assimilada ao papel de professora se coibisse a circulação das possíveis abordagens do tema proposto (a chamada "cola"). Ser comparada à professora pode trazer dificuldades para a pesquisa, como já discuti, uma vez que a relação professor-aluno baseia-se, em alguma medida, no pressuposto de que o primeiro sabe e o outro ignora. Se as crianças vêem a pesquisadora como aquela que sabe de tudo, pode ser difícil estabelecer uma relação direta e franca, em que elas sintam-se à vontade para expressar seus sentimentos e pensamentos. Apesar de alerta, no entanto, não pude deixar de ser assimilada como professora em alguns momentos. Com raras exceçōes, as crianças requeriam minha aprovação para os desenhos. Muito comumente elas perguntavam-me se estava "certo" o desenho que elas estavam começando a fazer ou se era assim mesmo que eu esperava que elas fizessem. Além disso, o modo como as mães, não as crianças, inquiriam-me, a fim de saber se podiam mandar seus filhos para minha casa, remete-me claramente ao universo pedagógico: "Flávia, tu vais ensinar hoje?". Outras vezes trocavam o verbo ensinar por atender. As crianças que já conhe- 
ciam o esquema de "ir para a casa de Flávia" sabiam que o que acontecia lá era pouco estudo e muita diversão.

Além disso, na análise dos desenhos e redações sistematicamente recolhidos segundo o corte de faixas etárias, há que se estar atento para o fato de que alguns desenhos não seguem a lógica-padrão esperada ${ }^{26}$ para aquela faixa etária em questão. São desenhos estranhos ao conjunto dos dados que, no entanto, são interessantes na medida em que mostram as idiossincrasias individuais e alertam para o fato de que uma abordagem desenvolvimental baseada em faixas etárias pode ser falaciosa - já que suprime as diferenças individuais. Esse viés pode ser minimizado se os desenhos são trabalhados em paralelo à observação participante. $\mathrm{O}$ antropólogo que conhece seu campo de estudos saberá distinguir um desenho que faz sentido no conjunto dos dados - por exemplo, antecipando uma tendência que está por vir na próxima faixa etária. De outro lado, parece-me possível tecer algumas considerações baseadas em faixas etárias distintas se elas não forem tomadas muito fixamente. Descobri que há importantes semelhanças na maneira de conceber a religião segundo uma determinada faixa etária - embora ao mesmo tempo haja idiossincrasias pessoais.

O desenho de uma criança aos 5 anos de idade, por exemplo, autoriza uma análise em um nível individual e pontual, que diz respeito apenas àquela criança naquele momento específico. No entanto, 20 desenhos de crianças aos 5 anos conduzem a uma abordagem que já não é apenas individual, mas aponta para observações coletivas, em harmonia com a faixa etária em questão. O que eu fiz foi, além disso, observar, em um único momento, como as crianças de variadas faixas etárias compreendiam um determinado assunto. Essa técnica nos permite observar diacronicamente como se dá o processo de tomada de conhecimento da religião e dos mal-assombros com o passar dos anos. Como resultado da pesquisa, temos um panorama geral que contém as diferenças na per- 
Flávia Pires. Ser adulta e pesquisar crianças...

cepção do tema proposto em relação a todas as idades em questão. Os dados podem ser analisados de dois pontos de vista diferentes. Temos um olhar datado e específico, que diz respeito a uma faixa etária ou a um indivíduo. Ao mesmo tempo, temos um olhar na perspectiva diacrônica, que diz respeito às mudanças na concepção do tema para as crianças com o passar dos anos, mas baseado nas observações coletivas. Em outras palavras, ao observar um único momento histórico, percebemos as mudanças, por meio das faixas etárias, que ocorreram no nível individual. Simultaneamente, essas mudanças devem ocorrer com todas as crianças naquela faixa etária. A abordagem é, assim, a um só tempo, individual e coletiva, histórica e etnográfica.

\section{Delimitando a realidade social das crianças: outras técnicas de pesquisa utilizadas}

Durante o trabalho de campo, foi feito um treinamento para o uso de minha máquina fotográfica com sete crianças, além de uma introdução às técnicas básicas de fotografia. Isso resultou em 32 fotografias realizadas pelas próprias crianças. Depois de reveladas, as fotografias foram discutidas, e cada uma das crianças escreveu sobre suas fotos. De modo geral, nas fotografias destacam-se: (1) a família, incluindo pai e mãe, mas, sobretudo, as crianças; (2) os elementos da natureza, particularmente no Açude do Prefeito e na Serra da Catingueira, com destaque para o nascer do sol e o pôr-do-sol; (3) os amigos. Destacam-se também alguns elementos religiosos, porém, em menor quantidade se comparados aos três temas mencionados. ${ }^{27}$

Cabe, mais uma vez, ressaltar que a classificação "elementos da natureza" e "família" é, em última instância, apesar de discutida com as crianças, da própria pesquisadora. ${ }^{28}$ As fotografias tiradas sugerem o que as 
crianças concebem como importante. Além disso, não é qualquer coisa importante que merece ser fotografada. Há que ser belo. Beleza e importância são os critérios escolhidos pelas crianças para se fotografar em Catingueira. As fotografias mostram que as crianças pinçam em seu cotidiano os elementos que elas consideram mais bonitos e dignos de serem eternizados. $\mathrm{O}$ fato de as crianças terem enfatizado a família pode ser entendido se lembrarmos que o mundo da criança é construído no cotidiano da família e em contato com os amigos e vizinhos próximos. Essas relações são o âmago da vida da criança. É principalmente no contato com a família que a criança vai aprender a se comportar como um catingueirense. Além disso, a família parece ser uma das instituiçôes sociais mais importantes segundo os catingueirenses - para maiores detalhes, ver Pires (2007).

A natureza, por sua vez, é tida como bela, e é a sua presença que torna Catingueira uma cidade bonita. Os elementos da natureza são usados, em muitos casos, como adorno. Mesmo não sendo o tema principal, eles estão presentes como ornamentação, por exemplo, em vaso de planta ou em uma flor. Interessante relembrar que os desenhos livres mais populares foram justamente os de elementos da natureza. Em segundo lugar, a casa foi o elemento mais destacado. Ela pode ser entendida como referência à família, na medida em que é a casa o lugar por excelência da mesma. Com tudo isso, verificamos que diferentes técnicas de pesquisa podem apresentar resultados complementares. Pouco pode ser dito sobre as crianças de Catingueira unicamente por meio das fotografias que elas tiraram. Entretanto, quando analisamos um conjunto de técnicas de pesquisa em contraste e relação, podemos melhor apurar a validade dos dados recolhidos.

Alderson (2000) alude à possibilidade de envolver as crianças como co-produtoras da pesquisa por meio das fotografias. Nesbitt (2000a) também utilizou a técnica e aponta como ponto positivo o fato de que a 
Flávia Pires. Ser adulta e pesquisar crianças...

criança se esquece de que está sendo pesquisada quando está tirando ou analisando suas fotos. Da mesma forma, Punch (2001) utilizou o recurso metodológico com sucesso na zona rural da Bolívia. Segundo minha experiência, o recurso das fotografias permite um acesso (parcial) ao mundo infantil na medida em que é possível tomar conhecimento daquilo que, dentre tudo o que está à sua volta, é considerado pela criança como o mais importante e bonito. Além disso, tirar fotos é como uma brincadeira especial. As crianças tomam contato com um equipamento alheio a seu cotidiano, o que torna a atividade bastante atrativa. $\mathrm{O}$ único inconveniente da técnica é o custo elevado das revelações, das ampliações e, principalmente, das câmaras fotográficas, que correm o risco de serem danificadas.

Complementarmente, sete meninas entre 10 e 13 anos mantiveram um diário por três meses, que, ao final, me foram entregues. Essa técnica também foi utilizada por Punch (2001) enquanto um meio de conhecer o dia-a-dia das crianças alfabetizadas. ${ }^{29}$ As meninas responderam com muito entusiasmo a essa técnica e elaboraram caprichados diários, repletos de gravuras, desenhos, colagens e fotos. Em princípio, os diários são um prato cheio para a pesquisa sobre a vida interior das crianças, já que contêm momentos de reflexão pessoal sobre os assuntos suscitados pelo cotidiano. A auto-reflexão que o ato de escrever um diário estimula é de grande valor para a pesquisa antropológica, na medida em que estão em jogo as experiências e os pensamentos próprios das crianças. Por meio do diário, é possível ter acesso a realidades normalmente restritas ao antropólogo, como as refeições em família. No entanto, o diário feito com o propósito de ser entregue à pesquisadora quando concluído parece ir em sentido oposto ao de sua definição enquanto algo pessoal e íntimo. ${ }^{30} \mathrm{Em}$ minha pesquisa, observei que, na maioria dos casos, as crianças fizeram do diário uma coletânea de cartas e recados endereçados à pesquisadora. Ao aplicar a técnica, é preciso ter em men- 
te que as crianças são espertas o suficiente para escreverem no diário apenas o que elas autorizam o pesquisador a tomar conhecimento.

Prosseguindo no mapeamento das técnicas utilizadas, também foi feita a gravação de um suposto "programa de rádio" por cada uma das religiōes representadas na cidade. Primeiro, conversei com as professoras de religião, e elas incumbiram-se de repassar a idéia às crianças. Essas professoras deveriam elaborar um pequeno programa de rádio explicando para as crianças das outras religiōes como é pertencer àquela denominação. A solicitação foi atendida pela igreja Católica, pela Assembléia de Deus e pelo Centro Espírita. Quanto à Igreja Congregacional, apesar de terem concordado com a proposta, não chegaram a efetivá-la. $\mathrm{Na}$ Igreja Seguidores de Cristo, foi-me alegado que não havia crianças entre os participantes. Todos os programas de rádio foram feitos com o auxílio e direcionamento de jovens mulheres que são encarregadas do ensino de religião para as crianças. De maneira enviesada, o que podemos perceber nas fitas cassete é, sobretudo, a visão de mundo das professoras de religião, e não tanto das próprias crianças. É interessante ressaltar que todas estas professoras de religião são, elas mesmas, adolescentes. Muitas vezes, ouve-se claramente sussurros ao fundo da gravação com o conteúdo a ser repetido pela criança. Além disso, a linguagem e o conteúdo da gravação são claramente não infantis. Esse viés está presente em todas as religiōes representadas. De modo geral, todas as gravaçôes contêm orações, cânticos e perguntas e respostas no estilo de entrevista. A Assembléia de Deus elaborou um programa de rádio de 60 minutos (!) - quando o solicitado foi em torno de 5 a 10 minutos - e requereu a aprovação e colaboração do pastor e de toda a "comunidade dos irmãos", enquanto na igreja Católica e no Centro Espírita a atividade não precisou da aprovação do padre ou do diretor do Centro, estando nas mãos das "professoras" a decisão de colaborar com a pesquisadora e com a execução do projeto. ${ }^{31}$ 
Flávia Pires. Ser adulta e pesquisar crianças...

Foram feitas também "entrevistas" abertas com crianças. De acordo com minha experiência, essa técnica limita a espontaneidade infantil. No caso estudado, as conversações informais foram usadas como substitutos das entrevistas com resultados mais positivos. As entrevistas exigem um aparato especial, como lugar reservado, hora marcada, gravador, estar sentado. As conversações, por sua vez, podem ter lugar a qualquer hora e em qualquer lugar. De outro lado, foram feitas entrevistas semiformais com adultos, com roteiro estruturado, a fim de compreender o que eles pensam sobre os mesmos temas desenhados pelas crianças e sobre a infância de modo geral. Mayall (2000, p. 129) também aposta nas entrevistas com adultos na pesquisa sobre criança. Ele afirma que, da mesma forma que o conceito de gênero é fundamental para se estudar as mulheres, o conceito de geração é essencial para se estudar crianças, já que vivemos em um mundo composto de pessoas com idades diferentes. ${ }^{32}$ Essa escolha teórico-metodológica conflita com a de Wartofsky (1983), Tammivaara e Enright (1986), Corsaro (1993, 2003, 2005), Thorne (1993), Sarmento e Pinto (1997), e Corsaro e Molinari (2000), para os quais as crianças constituem uma "cultura" ou "sociedade" específica e, portanto, devem ser estudadas em si mesmas. No entanto, incluir os adultos na pesquisa sobre criança tem a aprovação de outros pesquisadores, como Christina Toren (1999), Morton (1996) e Mayall (1995). Faço minhas as palavras de Morton quando concorda com Toren: "Eu compartilho a visão de Toren de que estudar crianças como se seu mundo social fosse, de alguma maneira, separado do dos adultos é fornecer uma análise inadequada" (Morton, 1996, p. 5 , tradução minha). ${ }^{33}$

Elaborei também um roteiro de filmagem tratando da vida religiosa das crianças, e de como elas interpretam os acontecimentos inexplicáveis ou misteriosos. As gravaçôes foram efetuadas em maio de 2005. Escolhi oito crianças para participar do filme. Contei com um roteiro semidi- 
Revista de Antropologia, São Paulo, USP, 2007, v. 50 No 1.

recionado de perguntas, que fui seguindo à medida da conveniência. As crianças escolhiam o lugar onde queriam que a gravação fosse feita. Dar às crianças a possibilidade da escolha do lugar da filmagem foi uma tentativa de distribuir o poder de decisão e fazer do filme algo construído com as crianças. Muitas delas escolheram gravar na Serra da Catingueira - o que mais uma vez destaca o papel especial reservado pelas crianças aos elementos chamados da natureza, já constatado nos desenhos livres e nas fotografias. Algumas filmagens foram feitas em duplas - nos casos nos quais as crianças eram grandes amigas ou muito tímidas -, mas a maioria das crianças foi filmada individualmente. $\mathrm{O}$ esforço resultou em quatro fitas de 60 minutos cada a serem editadas em momento oportuno. A técnica mostrou-se interessante. Além de ser muito bem-vinda pelas crianças, elas esmeram-se para parecerem inteligentes diante da câmara. Com isso, deixam-nos antever o que elas acreditam que os adultos querem ouvir, mostrando-se bastante conscientes sobre o mundo adulto. No entanto, há que se estar atento para o fato de que a câmara pode, às vezes, inibir a criança. Isso pode ser amenizado se a gravação das imagens é feita depois de um tempo considerável de trabalho de campo. Se as crianças confiam no pesquisador, provavelmente vão confiar nos instrumentos de pesquisa que ele propuser. Uma das meninas que participou do filme, ao contrário de se mostrar tímida ou arredia, tomou a oportunidade de estar sendo filmada para mencionar um fato bastante delicado da sua vida pessoal. Embora essa menina fosse uma das informantes mais próximas que tive, a ponto de nos tornarmos amigas, ela nunca tinha tocado naquele assunto previamente. Às vezes, a câmara inibe, às vezes, pode ser veículo de comunicação mais efetiva. ${ }^{34}$

Por fim, foram feitas também um total de 15 "cartas". Às crianças eram dados o papel e o lápis. A decisão do destinatário era definida pelo critério infantil. As cartas foram endereçadas a Jesus (6), pesquisadora (3), membros da família (2), Papai Noel (1), Papai do Céu (1), Deus 
Flávia Pires. Ser adulta e pesquisar crianças...

(1), Anjinho (1). A técnica mostrou-se com pouco apelo entre as crianças. Heller (1986) e Weisz (1980) pediram que as crianças escrevessem cartas para Deus, e, no caso de suas pesquisas, a técnica mostrou-se válida. Talvez eu devesse ter insistido um pouco mais na aplicação das cartas, já que, pelos poucos exemplares que coletei, se vislumbra um horizonte em que as crianças mostram-se bastante religiosas. Elas escolheram, em sua maioria, Jesus como o destinatário de suas cartas aliás, das 15 cartas elaboradas, 9 delas eram endereçadas a entidades do mundo espiritual! Não aprofundei essa técnica porque os desenhos eram tão mais populares que as crianças mesmas decidiram sobre a técnica mais aplicada.

\section{Conclusões}

Minha estratégia foi expandir ao máximo o espectro de possibilidades metodológicas na primeira etapa do trabalho de campo no ano de 2004, tentando cobrir todas as alternativas com as quais me deparei na literatura (Alderson, 2000; Berentzen, 1989; Fine \& Sandstrom, 1988; Heller, 1986; James \& Christensen, 2000; Mayall, 2000; Nesbitt, 2000b; Punch, 2001; Weisz, 1980). Na seqüência, fiz um apuramento das técnicas que se mostraram mais férteis e as desenvolvi mais intensamente na segunda etapa do trabalho de campo, no ano de 2005.

James e Christensen (2000), em um livro sobre a questão metodológica no estudo com as crianças, ${ }^{35}$ afirmam que estudar crianças não requer métodos especiais. De acordo com eles, de modo geral, os métodos de pesquisa devem ser adaptados ao contexto pesquisado. $\mathrm{O}$ mesmo vale para o contexto infantil. Não justificaria, assim, segundo os autores, desenvolver novos métodos de pesquisa destinados especialmente ao público infantil. No caso da entrevista, por exemplo, Alderson (1993) 
Revista de Antropologia, São Paulo, USP, 2007, v. 50 No 1.

afirma que as diferenças entre crianças e adultos são de grau, e não de tipo. Os adultos tendem a responder elaborando mais conexões e mais detalhadamente que as crianças. Mas isso se deve à inexperiência infantil, e não à imaturidade - já que, quando dominam o assunto, as crianças expressam-se com grande desenvoltura. Da mesma forma, continua Alderson, que o pesquisador pode encontrar uma criança tímida, pode deparar-se também com um adulto tímido (id., p. 71), o que dificultará a entrevista. Concordo com os autores citados quanto à validade de se utilizar os mesmos métodos e técnicas que utilizamos para os adultos com as crianças, como entrevistas e questionários. E concordo também que algumas adaptações são essenciais para o sucesso dos mesmos. Contudo, não tenho nada contra a criação e discussão de métodos e técnicas que atendam às especificidades infantis. Com isso, não quero dizer que os métodos e técnicas usados para pesquisar os adultos sejam muito complexos para o nível de entendimento infantil. Mas, sim, que as crianças e os adultos comportam-se de maneiras diferentes e respondem de maneiras igualmente diferentes aos diversos métodos e técnicas.

Dentre os métodos e técnicas utilizados nesta pesquisa, acredito que os que se mostraram mais eficazes para ela foram a boa e velha observação participante junto com os desenhos e as redações. Há que se ressaltar, mais uma vez, que os desenhos só são realmente interessantes para a pesquisa antropológica quando elaborados naquele contexto em que a criança é levada a refletir e a elaborar oralmente ou textualmente sobre o que ela desenhou. ${ }^{36} \mathrm{~A}$ pesquisa em antropologia não pode se valer apenas dos desenhos em si mesmos. Mas, se são conjugados com a observação participante, me parece que as duas técnicas reforçam-se mutuamente: os desenhos indicam a direção que a observação deve tomar.

Além disso, dada a relativa novidade do estudo antropológico das crianças, parece-me útil a experimentação de técnicas pouco usuais, como o diário, a fotografia, o filme, o programa de rádio e a carta. Além 
Flávia Pires. Ser adulta e pesquisar crianças...

disso, quanto mais variadas as técnicas aplicadas, melhor a compreensão da realidade a ser estudada. Até mesmo para se chegar à conclusão de quais técnicas são mais adequadas a um objeto específico na área da infância, considero positivo extrapolar o cânone antropológico da observação participante. Embora em meu caso a observação participante e os desenhos/redações tenham sido mais utilizados, as outras técnicas em conjunto foram essenciais para a delimitação da realidade social infantil em Catingueira.

Uma nota de esclarecimento faz-se necessária. A observação participante é o método por excelência da antropologia - com o que eu estou de completo acordo. Longe de mim querer contestar sua eficácia. O que ressalto, todavia, é que, apesar de minha pesquisa ter sido construída em grande medida por meio do recurso da observação participante intensiva e prolongada, isso não impediu a aplicação de outras técnicas de pesquisa, necessárias pelas particularidades do objeto trabalhado. As crianças foram pesquisadas tendo como suporte metodológico os desenhos e todas as outras técnicas descritas acima. Com os adultos, utilizei as entrevistas como técnica complementar, embora, destaco novamente, é da observação participante que tirei os melhores frutos. No entanto, não fiz desenhos com os adultos e, assim, em relação a estes, não posso fornecer dados quantitativos, como é o caso das crianças - para maiores detalhes, ver Pires (2007). A opção por não fazer desenhos com adultos vem do fato de que são raros os que têm por hábito desenhar. Os adultos que desenham em Catingueira são aqueles nos quais é reconhecido um dom especial para as artes - ao contrário das crianças, que são facilmente envolvidas na atividade, seja por prazer, seja por obrigação escolar. ${ }^{37}$

Para finalizar, quanto ao fato de ser adulta e pesquisar crianças, parece-me que a especificidade do objeto exigiu que a pesquisadora estabelecesse uma relação que difere daquela relação corrente entre as crianças e os adultos na cidade pesquisada. Isso criou problemas. Uma vizinha 
Revista de Antropologia, São Paulo, USP, 2007, v. 50 oo 1.

espalhou a fofoca sobre minha suposta imperícia como adulta responsável, o que, por sua vez, levou à proibição de algumas crianças de freqüentarem minha casa. De uma perspectiva antropológica, o pesquisador deve ser capaz de observar a comunidade de uma perspectiva interna. Isso não quer dizer que ele deva transformar-se em nativo, mas, sim, que as suas dessemelhanças em relação aos nativos não sejam um impeditivo para a relação. Um dos desafios do pesquisador é conseguir manejar sua presença no campo, de modo que respeite as normas de interação social reinantes e as especificidades daquela comunidade, ao mesmo tempo em que consiga se inserir de maneira efetiva a fim realizar sua pesquisa satisfatoriamente.

\section{Notas}

1 Este artigo é uma reelaboração do primeiro capítulo de minha tese de doutorado, recentemente defendida no Programa de Pós-Graduação em Antropologia Social do Museu Nacional-UFRJ, cujo título é Quem tem medo de mal-assombro? Religião e infância no semi-árido nordestino. $\mathrm{O}$ artigo também foi apresentado, em fase preliminar, na 25 $\mathrm{ABA}$ - Reuniāo Brasileira de Antropologia, realizada em Goiânia, no ano de 2006, no GT 41 - "Por uma antropologia da infância”.

2 Desde os primeiros contatos em Catingueira, pedi que me chamassem apenas por meu primeiro nome. Os que se tornaram mais íntimos acabaram por me chamar apenas de "Flavinha" - tanto crianças quanto adultos -, embora outros continuassem me chamando de "senhora" ou "doutora".

3 Citação completa: "What is so wrong with 'mere descriptions?? A good text is never an unmediated portrait of what it describes - nor for that matter is a portrait. It is always part of an artificial experiment to replicate and emphasize the traces generated by trials in which actors become mediators or mediators are turned into faithful intermediaries. There is nothing less natural than to go into fieldwork and remain a fly on the wall, pass out questionnaires, draw maps, dig up archives, record interviews, play role of a participant-observer, compile statistics, and 'Google' one's way around the Internet. 
Flávia Pires. Ser adulta e pesquisar crianças...

De-scribing, inscribing, narrating, and writing a final report are as unnatural, complex, and painstaking as dissecting fruit flies or sending a telescope into space. If you find Faraday's experiments oddly artificial, what about Pitt-Rivers's ethonographic expeditions? If you believe Lord Kelvin's laboratory contrived, what about Marx compiling footnotes in the British Library, Freud asking people to free-associate on his Viennese couch, or Howard Becker learning how to play jazz in order to take notes on jazz playing? The simple act of recording anything on paper is already an immense transformation that requires as much skill and just as much artifice as painting a landscape or setting up some elaborate biochemical reaction. No scholar should find bumiliating the task of sticking to description. This is, on the contrary, the highest and rarest achievement" (Latour, 2005, pp. 136-7).

4 Mesmo assim, um dia, de manhãzinha, um menino pulou o muro pela casa da vizinha, vindo ter comigo na janela do quarto dos fundos, onde eu dormia. Outro dia, ainda, quando eu estava começando a organizar os desenhos, resolvi fechar a porta e as janelas da frente para evitar visitas. Estava bem concentrada trabalhando quando escutei chamarem meu nome insistentemente na porta. Pensava comigo: “mas como eles sabem que estou em casa?". Como não foi possível disfarçar, fui abrir a porta. A senhora que me esperava disse que, quando viu a casa fechada, pensou que eu não estava. Mas mudou de idéia quando, atenta, observou que a chave estava do lado de dentro da fechadura.

5 Apesar da semelhança com o ambiente escolar, onde os professores dão as tarefas e depois liberam as crianças para brincar, parece que as crianças associavam as atividades em minha casa muito mais com diversão que com trabalho escolar, já que até o que eu considerava o trabalho era para elas uma atividade de lazer (o desenho). Sem falar que a atividade em casa não tinha caráter obrigatório nem resultava em avaliação.

6 Muitas casas em Catingueira não têm sofá, que é tido como móvel de luxo. Nas casas tipicamente sertanejas, a sala, primeiro ambiente de uma casa depois da porta da rua, é lugar onde geralmente os filhos rapazes ou eventuais visitas masculinas dormem. Durante a noite, as redes são armadas e, durante o dia, elas são dobradas e penduradas em cima do próprio armador de redes, deixando o chão da sala vazio de móveis. Algumas casas possuem tamboretes ou bancos de madeira que serão dispostos para o uso das visitas. A sala é também usada para armazenar os produtos da lavoura quando não se dispõe de um cômodo para esse fim. A cozinha, por sua 
Revista de Antropologia, São Paulo, USP, 2007, v. 50 № 1.

vez, está localizada em direção oposta à sala, como o cômodo mais distante da rua. Poderíamos sugerir que a cozinha é o lugar por excelência da mulher, assim como o muro (quintal), enquanto a sala seria o lugar por excelência da esfera do masculino - dentre outras coisas, porque os produtos do roçado, cultivado geralmente pelo pai de família, ali estão colocados. Ver Heredia (1979, pp. 89-97) para consideraçôes sobre a casa na área da zona da mata pernambucana. Ver também Bourdieu (1970) para uma análise socioantropológica da casa kabila. Ver Da Matta (1991) para reflexōes sobre a casa e a rua.

7 Recorra a Pires (2007, pp. 77-94), em que discorro sobre as relaçôes entre os adultos e as crianças.

8 Margaret Mead (1932) também afirma que nunca orientava ou repreendia um comportamento (ou um desenho) das crianças, a não ser quando elas corriam perigo e que, do mesmo modo, mantinha a sua casa sempre aberta para as mesmas. Mary Catherine Bateson (1994), no livro em que trata de suas memórias infantis em relação aos pais (Margaret Mead e Gregory Bateson), descreve como a própria infância serviu de teste para as idéias de uma pedagogia libertária associadas ao dr. Spock, amigo do casal. Dessa forma, o espontaneísmo com o qual Mead conduzia suas pesquisas parece ser apenas aparente: deixar as crianças "livres" era parte do projeto de pesquisa empreendido pela pesquisadora.

9 O catecismo tem lugar em um prédio de escola desativado, utilizado pela igreja Católica para o catecismo e para outras atividades. Embora crianças com variadas idades compareçam, predominam aquelas que pretendem fazer a primeira eucaristia ao fim do ano, que têm por volta dos 11 anos de idade.

10 Para uma análise crítica da noção de se tornar nativo, ver Marcio Goldman: "Melhor seria ouvir a advertência levistraussiana: 'não é jamais ele mesmo nem o outro que ele [o etnógrafo] encontra ao final de sua pesquisa' (Lévi-Strauss, 1960, p. 17). De toda forma, penso que a perspectiva de Lévi-Strauss sobre o trabalho de campo e da etnografia articula-se estreitamente com a idéia estruturalista de que cada sociedade atualiza virtualidades humanas universais e, portanto, potencialmente presentes em outras sociedades: o nativo não é mais simplesmente aquele que eu fui (como ocorre no evolucionismo), ou aquele que eu não sou (como ocorre no funcionalismo), ou mesmo aquele que eu poderia ser (como ocorre no culturalismo); ele é o que eu sou parcial e incompletamente (e vice-versa, é claro)" (2003, pp. 462-3). Marcio Goldman sugere pensar a noção de "devir nativo" que 
Flávia Pires. Ser adulta e pesquisar crianças...

implica ser "afetado" (Favret-Saada, 1990; Deleuze \& Guatarri, 1997) pelas mesmas forças que afetam os nativos (Goldman, 2003, pp. 463-5).

11 Talvez o leitor faça uma objeção ao argumento, afirmando que a maneira como a pesquisadora aproximou-se das crianças, como um "adulto diferente", não passe de um estereótipo de um adulto liberal das classes médias dos estados do Sul e Sudeste brasileiros. Assim, ao invés de se aproximar das crianças, a pesquisadora teria afirmado seu etnocentrismo em relação àquela comunidade. No entanto, tendo tido contato com outros adultos do Sul e Sudeste, os chamados "filhos-ausentes", que vêm visitar a cidade durante a Festa do Padroeiro, foi possível constatar que nenhum deles comportava-se como a pesquisadora em relação às crianças. As suas atitudes para com as crianças diferiam das dos catingueirenses, mas não eram, de maneira alguma, da mesma natureza das da pesquisadora. Destarte, mesmo fazendo pesquisa nos estados do Sul e Sudeste, seria necessário descobrir um modo de interação com as crianças que as deixasse confortáveis o bastante na frente do pesquisador. Acredito que, neste outro contexto fictício, agindo apenas como um adulto liberal do Sul e Sudeste, a pesquisa não poderia ser levada a cabo a contento.

12 "A língua do "pê" consiste em acrescentar, no final de cada sílaba da palavra, uma sílaba formada com a letra P mais o fim da sílaba original. Veja os exemplos: Você $=$ vo+po+cê+pê. Gato = ga+pa+to+pó. Menino = me+pe+ni+pi+no+pó". (Jangada Brasil, n. 4, dez. 1998 - http://jangadabrasil.com.br/dezembro/ca41200b.htm, acessado em 11 de junho de 2006). A língua do "pê" também pode ser vista como a língua das crianças, bem ao gosto dos pesquisadores que advogam uma "cultura infantil" ou "sociedade infantil", com regras, dinâmicas, rituais e até língua próprias e, por princípio, distintas daquelas dos adultos (Wartofsky, 1983; Tammivaara \& Enright, 1986; Corsaro, 1993, 2003, 2005; Thorne,1993; Sarmento \& Pinto,1997; Corsaro \& Molinari, 2000). Por exemplo, Corsaro afirma: "In attempting to make sense of the adult world, children come to collectively produce their own peer worlds and cultures" (2005, p. 24). Poderíamos fazer duas objeçôes à afirmação de que as crianças inventam uma língua própria independente dos adultos. Primeiro, os adultos que aprenderam a língua do "pê" quando crianças não a esquecem quando se tornam adultos. No entanto, o uso da língua do "pê" por parte dos adultos leva a um sentimento de inadequação, o que contribui para seu desuso. Assim, podemos reafirmar a sua particularidade como língua infantil. A segunda objeção é o fato de que os adultos também conversam entre si de maneira 
Revista de Antropologia, São Paulo, USP, 2007, v. 50 No 1.

cifrada quando querem que a criança não entenda. O fato é que, geralmente, a criança sabe que os adultos estão tratando de algum assunto importante, que segundo os últimos não lhes diz respeito, embora ela talvez não possa precisar o conteúdo da conversa.

13 Hildred Geertz faz algumas reflexões interessantes sobre o uso dos desenhos para a análise antropológica em virtude dos desenhos coletados por Mead e Bateson em Bali: "We uneasily ask ourselves questions: What in them comes from the desire of their makers to please foreigners? What derives from their own cultural preoccupations, their own aesthetic values, and their own ways of seeing? How much did these painters simplify their subjects and prettify the images they confected in order to satisfy purchasers whom they saw as ignorant, godless, and tasteless? When I look at their works, am I projecting onto them my own, perhaps romantic, notions of what Bali and the Balinese are, or where at that time? I have met these concerns in the only way that I knowthrough a redoubling of my efforts as an anthropologist to get at implicit Balinese view of life and the world" (Geertz, 1995, p. 3). Ela também afirma que "[...] these paintings provide complex interpretations of the deeper meaning underlying the outer visible shell of Balinese life" (ibid.).

14 Toren (2002) também é favorável ao uso do desenho conjugado com a observação participante, dentre outras razôes, por incluir os adultos. Vide citação: "This sistematic study requires the use of diagnostic tasks, which maybe be quite simple in form - for example, asking children to make a drawing of a particular scene and then talking with them one by one about what they have drawn. This kind of proceeding with children is equivalent to open-ended interwiews with adults. There is no point, however, in focusing on children to the exclusion of adults. Moreover, long-term participant-observer study remains absolutely necessary, for without it the anthropologist cannot know where it will be fruitful to focus any more systematic investigations with children" (Toren, 2002, pp. 118-19).

15 Cohn (2006) chama de desenhos espontâneos aqueles que as crianças xikrin faziam por iniciativa própria e com temas por ela escolhidos.

16 Dentre os religiosos: São Sebastião, Maria Mãe de Jesus, cruz, Smilingüido, Anjinho, Rainha do Céu, uma bailarina dançando com um hexágono na ponta dos dedos onde está escrito "Deus", igreja, cemitério, terço, promessa, Jesus, São Antônio com bengalinha, floresta com o nome DEUS escrito. Dentre os de malassombro: Maria Fumaça, Maria Fulorzinha, Carneiro de Ouro, Peixe de Ouro, 
Flávia Pires. Ser adulta e pesquisar crianças...

Rasga-Mortalha, fantasma, casa da bruxa, Homem do Saco, ET de Marte. Sobre os mal-assombros, ver Pires (2007).

17 Todos os temas abaixo descritos foram desenhados (e classificados por idade e gênero):

Questôes da politica: Em quem você votaria (para prefeito e vereador) e por quê? Em quem você não votaria (para prefeito e vereador) e por quê?

Questôes da vida prática: Desenhar Catingueira. A serra e o que tem nela. O que você compraria se alguém lhe desse um bolo de dinheiro? O que fizeram no domingo? Algo bom que aconteceu hoje. Coisas anormais, fora do normal. Do que você mais gosta de brincar? Um sítio. Um cangaceiro. Você, no seu aniversário dos sonhos. Coisas que eu gosto e não gosto de comer.

Questōes da alteridade: Desenhar um índio, desenhar "O Índio" “O Índio" era um descendente de índios, morador do Recife, que passou uns dias de férias na cidade). Questôes do self: De quem eu gosto? Como serei quando eu for grande? Como será a minha vida quando eu for grande? Desenho de si mesmo.

Questôes sobre a família: Desenhar sua futura família. A avó. O avô. Uma mãe, um pai e um filho. Algo sobre o dia dos pais. Uma família. De quem você mais gosta e de quem menos gosta na sua família? Uma família - que não seja a sua. Um velho e uma criança. O seu pai e a sua mãe.

Questōes sobre as entidades: A Maria Fulorzinha. O Homem do Saco. A RasgaMortalha. A Mulher de Branco. O Papa-Figo. A Cabeça da Estrada. O Carneiro de Ouro. A Gia Encantada. Histórias da Serra da Catingueira.

Questôes morais: A coisa mais bonita do mundo. A coisa mais feia do mundo. Algo que dá medo. A coisa mais triste e mais alegre do mundo. Seu maior sonho. A pior coisa que pode acontecer. A coisa mais feliz, a mais triste e o que lhe deixa com mais ódio. A coisa mais importante na minha vida. Um recado para outras crianças que você não conhece.

Questōes sobre religiāo: Desenhar Deus. O anjo da guarda. Fazer um desenho para Jesus. O que eu aprendi na igreja. O padre, o pastor, Doutor Fernando (diretor do Centro Espírita).

Questôes sobre a morte: Alguém que morreu e de quem você gostava. Alguém que já morreu. Um homem bom. Um homem mau. Uma mulher boa. Uma mulher má. Um homem mau e um homem bom - quando morreu, para onde eles foram? Para maiores informaçóes sobre os desenhos, recorra a Pires (2007, pp. 39-65). 
Revista de Antropologia, São Paulo, USP, 2007, v. 50 № 1.

18 Na dissertação de mestrado defendida por mim (Pires, 2003), trabalhei sobre a relação entre os "de dentro" e os "de fora" enquanto categorias êmicas que designam aqueles que moram e aqueles que não moram em Catingueira, por meio de qualidades morais intrínsecas. Os "de dentro" são pensados sempre como inferiores aos "de fora". É na festa do padroeiro da cidade que essas categorias são atualizadas e potencializadas como referentes sociais. Causa impressão, no entanto, que a grande maioria das autoridades da cidade não resida ali. $\mathrm{O}$ médico, o prefeito, os vereadores, os maiores proprietários de terras e, como destaquei acima, também a diretora do colégio não residem em Catingueira. Isso afirma a hipótese sugerida. Um lugar hierarquicamente inferior é reservado aos que moram ali, mas que, uma vez sendo autoridades, ou seja, hierarquicamente superiores, não poderiam compartilhar a inferioridade com o resto dos habitantes, vivendo na cidade. É interessante que um ex-prefeito da cidade ali tenha residido durante seu mandato. Dentre os outros prefeitos, este, em especial, goza de status diferenciado, sendo considerado "gente pobre como a gente", "gente do povo", não escolarizado e, por alguns, ignorante. Mísia Reesink (2006) expandiu em abrangência os conceitos "de dentro" e "de fora" enquanto categorias definidoras nas festas religiosas.

19 Os desenhos das crianças foram classificados e aparecem no texto da tese da seguinte forma: iniciais do nome da criança, idade, sexo, número do desenho dentre aquela faixa etária. Um exemplo: EF 16. M. 3. Donde, EF. são as iniciais do nome da criança, 16 é a sua idade, $\mathrm{M}$ indica masculino e, por fim, 3 é o número do desenho na faixa etária dos 16 anos.

20 "Fantasma. Era um lindo dia de lua quando uma pessoa de branco veio em minha direção. Quando eu olhei era uma pessoa do sexo feminino, ou seja, era uma mulher morena, de cabelo longo e era também muito bonita parecida com essa mulher de óculos. Ela quis me dá alguma [coisa] ou me dizer, só que eu não estava só e aí ela só aparecia para mim. Não sei nem porque, só sei que o outro não via nada nem ninguém. Isso aconteceu umas quatro vezes e depois que ela veio pela última vez, eu perguntei o que era que ela queria comigo. Ela respondeu que queria me dá alguma coisa chamada de botija. Só que eu não tive coragem de responder se eu queria ou não e ela foi embora para sempre, e depois desse dia eu não a vi mais. Eu acho que ela deu para outra pessoa que teve coragem de arrancar."

21 Além disso, no caso dos desenhos livres e temáticos feitos em minha casa, a fim de incentivar a feitura deles, algumas vezes foram fornecidas revistas semanais anti- 
Flávia Pires. Ser adulta e pesquisar crianças...

gas para a realização de recortes e colagens. Em uma dessas colagens, C. 7. F. selecionou de uma revista a figura de um homem de terno e gravata, segurando um guarda-chuva, sob a chuva que caía abundante. A menina recortou a figura, mas deixou de fora a chuva. Colou a figura do homem no papel e escreveu: "Que sol quente!". O exemplo nos alerta para as particularidades de uso e interpretação dos objetos. Para uma criança que raramente vê chuva, o guarda-chuva é antes associado aos dias quentes nos quais é necessário proteger-se do sol usando esse tipo de utensílio. Além disso, em dias muito quentes, quem vai ao sol usa roupa de manga comprida para se proteger, como o terno do homem da revista.

22 Talvez uma análise que não se restringisse apenas ao que as crianças dizem sobre os desenhos, mas se ativesse também ao próprio desenho, fosse interessante e revelasse aspectos que a técnica aqui utilizada não permite. No entanto, como não tenho formação em psicologia, iconografia ou artes, não poderia trabalhar os desenhos senão como uma antropóloga. Entretanto, parece-me claro que o desenho, quando utilizado como técnica complementar à observação participante, pode ser um instrumento rico de pesquisa para a antropologia.

23 Vide um exemplo de árvore mal-assombrada (Desenho Livre de P. 10. F.): "A Árvore Mal-Assombrada. Era uma vez uma árvore mal-assombrada. Ela tinha dois olhos e era muito malvada. $\mathrm{O}$ nome dessa árvore era árvore mal-assombrada. As crianças e os adultos quando passavam perto daquela árvore, ela comia as crianças e os adultos. Um dia as polícias se vestiram de árvore para matar a árvore”.

24 As autoras esqueceram-se de acrescentar que isso se dá apenas quando se trata de sociedades com tradição pictográfica.

25 Como Cohn (2006) afirma, Mead não interferia sequer promovendo temas de desenho. Os desenhos com os quais a autora trabalhou foram desenhos aos quais eu chamaria de livres. Sobre o espontaneísmo da pesquisa de Mead, recorra à nota 8 deste artigo.

26 Por lógica-padrão esperada, considero o que foi mais desenhado naquela faixa etária sobre um determinado tema.

27 Fotos (julho de 2004): o olhar infantil sobre o mundo - o que é considerado digno de uma foto, o que é bonito ou importante o bastante para ser fotografado.

F. 11. F.

1) Mãe e amigas voltando da caminhada com as montanhas refletindo a água do açude. 
Revista de Antropologia, São Paulo, USP, 2007, v. 50 No 1.

2) Nascer do sol.

3) Amigas na paisagem ("aniversário de uma delas: quebraram ovos na sua cabeça, foi muito engraçado").

4) Centro Espírita de dentro.

5) Bonecas ("simbolizam a minha infância").

A. 11. F.

1) Amigos que ensaiavam uma quadrilha na sua casa.

2) Rocinha do pai.

3) Centro Espírita de fora. "Idéia das irmãs mais velhas: ia tirar do primo M., mas ele viajou".

4) Gatinho na cozinha de sua casa.

5) Família dentro de casa: mãe, pai e irmã (os outros irmãos recusaram-se).

L. 12. F.

1) Amiga e irmã na serra.

2) Pai ralhando milho.

3) Pôr-do-sol. Sua casa com mãe, pai e outros na porta (difícil visualização).

4) Açude, "pegando" a serra. "Quando a água brilha, parece os olhos de minha mãe."

5) Irmã caçula.

S. 12. F.

1) Pesquisadora.

2) Rangel, namorado, sem camisa, andando pela rua principal, com Catingueira (centro) aos fundos.

3) O pôr-do-sol no açude.

4) Açude.

5) Gato na porta da cozinha.

R. 12. F.

1) Irmão, afilhada de consagração, amigas e a serra ao fundo, onde ela morou três anos.

2) Filha da madrinha. "V. (amiga que foi criada bem dizer junta) está segurando a menina."

3) Serra com paredão/barragem.

4) Pai e tio trabalhando na serra.

J. 14. M. 
Flávia Pires. Ser adulta e pesquisar crianças...

1) A televisão na tela do Super Mário/videogame.

2) Duas primas.

3) "Primo de 1 ano e 4 meses mais as duas primas (ele não quis tirar sozinho)."

4) Nossa Senhora de Fátima ("Eu tenho uma santa"). (Foto não revelada.)

5) Amigas.

R. 13. M.

1) Amigo.

2) Ensaio religioso no salão paroquial, meninas/amigas.

3) Amigos (só meninas).

Ocorrências: natureza, 9; família, 6; amigos, 3; brinquedos, 2; religião, 2; pesquisadora, 1; namorado, 1; natureza/família e amigos, 1; natureza e família, 1; religião e amigos, 1; família e amigos, 2.

28 Sobre o uso do termo "elementos da natureza" enquanto categoria da pesquisadora, recorra às considerações elaboradas no início do tópico 2 deste artigo.

29 Ver também Sinats et al. (2005) para um estudo da espiritualidade de meninas adolescentes por meio de diários e poesias.

30 "A tradição do diarismo só se tornará predominantemente íntima (a ponto de se hoje pensar um diário sempre como um objeto da intimidade) a partir da segunda metade do século XIX na Europa e, mesmo assim, só no século XX é que podemos falar de uma ampla prática de diarismo íntimo" (Pires, em preparação).

31 A idéia inicial era divulgar as fitas cassete na rádio falante da igreja Católica, que funciona como a rádio na cidade, divulgando notícias e anúncios com vistas a estimular a discussão ecumênica. No entanto, a divulgação dos programas de rádio ainda não foi realizada.

32 Os catingueirenses, por sua vez, pensam o mundo das crianças, conforme já anunciei, como separado do mundo dos adultos. Ver mais detalhes sobre a concepção de infância na cidade em Pires (2007, pp. 73-95).

33 Ver nota 14 . A situação criada em minha casa poderia ser, dessa forma, considerada imprópria para a pesquisa, já que as crianças não estariam ali em contato com os adultos. No entanto, parece-me que o experimento é válido na medida em que também analisei as crianças em interação cotidiana com os adultos.

34 Há uma considerável bibliografia brasileira sobre o uso da câmara e a produção de vídeos em antropologia, assim como sobre o uso da câmara fotográfica. Ver, por exemplo, o projeto Vídeo nas Aldeias (http://www.videonasaldeias.org.br), Sylvia 
Revista de Antropologia, São Paulo, USP, 2007, v. 50 No 1.

Caiuby Novaes (1993) e Rose Satiko Gitirana Hikiji (1998), ambas do Grupo de Antropologia Visual (GRAVI-USP), e Ruben Caixeta de Queiroz (2004). Para uma abordagem clássica, ver Jean Rouch, cuja vasta bibliografia pode ser contemplada em http://www.jeanrouch.com/.

35 Allison James e Pia Christensen (2000) advogam contra a pesquisa sobre crianças em favor de uma research with children, que, até mesmo, dá título ao livro organizado pelas autoras. A tentativa é envolver as crianças como co-construtoras da pesquisa, como informantes ativas ou como sujeito de ação social. De minha parte, tenho simpatia pelo projeto, mas não considero que apenas o uso ou não de uma palavra possa determinar os rumos de uma pesquisa; por isso, continuo utilizando construçōes consideradas ultrapassadas, como pesquisar crianças..., como aparece no título neste artigo.

36 Afirmação com a qual Christina Toren $(1999,2002)$ concordaria.

37 Como já foi citado, Mead e Bateson coletaram mais de 1.200 desenhos (e relatos sobre eles) na ilha de Bali, durante os anos de 1937 a 1939, em sua grande maioria feitos por adultos considerados artistas, o que difere em natureza dos desenhos aqui apresentados (Geertz, 1995).

\section{Bibliografia}

ALDERSON, Priscilla

$1993 \quad$ Children's Consent of Surgery, Buckingham, Open University Press.

2000 "Children as Researchers. The Effects of Participation Rights on Research Methodology”, in JAMES, Allison \& CHRISTENSEN, Pia (eds.), Research with Children. Perspectives and Practices, London/New York, Falmer Press.

BATESON, Mary Catherine

1994[1984] With a Daughter's Eye. A Memoir of Margaret Mead and Gregory Bateson, HarperPerennial.

BERENTZEN, S. (ed.)

1989 "Ethnographic Approaches to Children's Worlds and Peer Cultures", The Norwegian Centre for Child Research, Report n. 15, Trondheim, Norway. 
Flávia Pires. Ser adulta e pesquisar crianças...

BOURDIEU, Pierre

1970 "La Maison Kabile ou le Monde Renvérse", in POUILLON, J. \& MARANDA,

Pierre (eds.), Echanges et Communications. Mélanges offertes à C. Lévi-Strauss à

loccasion de son 60e. anniversaire, Paris, La Haye, Mouton, pp. 739-58.

CAIXETA DE QUEIROZ, Ruben

2004 Politica, estética e ética no Projeto Vídeo nas Aldeias, catálogo da Mostra Vídeo nas Aldeias - um Olhar Indígena.

COHN, Clarice

2006 "O desenho da criança e o antropólogo: reflexões a partir das crianças Mebengokré-Xikrin", texto apresentado no GT 41: "Por uma antropologia da infância”, na 25a Reunião Brasileira de Antropologia, Goiânia.

CORSARO, William A.

1993 "Interpretative Reproduction in Children's Role Play", Childhood, 1, pp. 64-74.

2003 "We're Friends, Right?" Inside Kids'Culture, Washington, Joseph Henry Press.

2005[1997] The Sociology of Childhood, London/New Delhi, Thousand Oaks/Pine Forge Press.

CORSARO, William A. \& MOLINARI, Luisa

2000 Entering and Observing in Children's Worlds: a Reflection on a Longitudinal Ethnography of Early Education in Italy.

DA MATTA, Roberto

1991 A casa e a rua, Rio de Janeiro, Guanabara Koogan.

DELEUZE, Gilles \& GUATTARI, Félix

1997[1980] Mil Platôs, São Paulo, Editora 34.

FAVRET-SAADA, J.

1990 "Être affectê", Gradhiva. Revue d'Histoire et d'Archives de Anthropologie, 8, pp. 3-9.

FINE, A. \& SANDSTROM, Kent L.

1988 Knowing Children: Participant Observation with Minors, California, Sage Publications. 
Revista de Antropologia, São Paulo, USP, 2007, v. 50 No 1.

GEERTZ, Hildred

1995 Images of Power. Balinese Paintings Made for Gregory Nateson and Margaret Mead, University of Hawaii Press.

GOLDMAN, Márcio

2003 "Os tambores dos mortos e os tambores dos vivos. Etnografia, antropologia e política em Ilhéus, Bahia”, Revista de Antropologia, vol. 46(2): 423-44.

HELLER, David

1986 The Children's God, Chicago, University of Chicago Press.

HEREDIA, Beatriz

1979 A morada da vida. Trabalho familiar de pequenos produtores do Nordeste do Brasil, Rio de Janeiro, Paz e Terra.

HIKIJI, Rose Satiko Gitirana

1998 "Antropólogos vão ao cinema - observações sobre a constituição do filme como campo", Cadernos de Campo, vol. 7, pp. 91-113.

JAMES, Allison \& CHRISTENSEN, Pia (eds.)

$2000 \quad$ Research with Children. Perspectives and Practices, London/New York, Falmer Press.

JAMES, Allison; JENKS, Chris; PROUT, Alan

$1998 \quad$ Theorizing Childhood, Polity Press.

LATOUR, Bruno

2005 Reassembleing the Social. An Introduction to Actor-Network-Theory, Oxford, Oxford University Press.

MAYALL, B.

1995 "Children as a Minority Group: Issues and Prospects", paper presented to the Seminar on Childhood and Society, Institute of Education, London.

2000 "Conversations with Children. Working with Generational Issues", in JAMES, Allison \& CHRISTENSEN, Pia (eds.), Research with Children. Perspectives and Practices, London/New York, Falmer Press, pp. 120-34. 
Flávia Pires. Ser adulta e pesquisar crianças...

MEAD, M.

1932 "An Investigation of the Thought of Primitive Children, with Special Reference to Animism", Journal of the Royal Anthropological Institute, 62, pp. 173-90.

MORTON, Helen

1996 Becoming a Tongan. An Ethnography of Childhood, Honolulu, University of Hawaii Press.

NESBITT, Eleanor M.

2000a The Religious Lives of Sikh Children: a Coventry Based Study, Univesity of Leeds. 2000b "Researching 8 to 13 Years Olds. Perspectives on Their Experience of Religion”, LEWIS, A. \& LINDSAY, G. (eds.), Researching Children's Perspectives, Buckingham, Open University Press.

NOVAES, Sylvia Caiuby

1993 Jogo de espelhos: imagens da representação de si através dos outros, São Paulo, Edusp.

PIRES, Flávia Ferreira

2003 Os filhos-ausentes e as penosas de São Sebastiāozinho. Etnografia da Festa da Catingueira/PB, Rio de Janeiro, dissertação, Museu Nacional, UFRJ.

2007 Quem tem medo de mal-assombro? Religiäo e infância no semi-árido nordestino, Rio de Janeiro, tese, Museu Nacional, UFRJ.

PIRES, João Ricardo Ferreira

no prelo Notas de viagem: o diário do imperador Dom Pedro II e sua visita a Minas, 1881 (título provisório).

PUNCH, Samantha

2001 "Multiple Methods and Research Relations with Children in Rural Bolivia", LIMB, M. \& DRUYER, C. (eds.), Qualitative Methods for Geographers, London.

REESINK, Mísia Lins

2006 “Os de 'dentro' e os de 'fora' no Monte Santo: festas religiosas e diferenças sociais entre nativos e forasteiros”, texto apresentado na 25a Reunião Brasileira de Antropologia, Goiânia. 
Revista de Antropologia, São Paulo, USP, 2007, v. 50 No 1.

SARMENTO, Manuel J. \& PINTO, Manuel

1997 "As crianças e a infância: definindo conceitos delimitando o campo", in PINTO, Manuel \& SARMENTO, Manuel J. (orgs.), As crianças - contextos e identidades, Braga, Portugal, Centro de Estudos da Criança.

SINATS, P.; SCOTT, D. G.; MCFERRAN, S.; HITTOS, M.; CRAGG, T.; LEBLANC, T.; BROOKS, D.

2005 "Writing Ourselves into Beings: Writing as Spiritual Self-Care for Adolescent Girls. Part One", The International Journal of Children's Spirituality, vol.10(1): 17-29, April.

TAMMIVAARA, Julie \& ENRIGHT, D. Scott

1986 "On Eliciting Information: Dialogues with Child Informants", Anthropology and Education Quarterly, 17, pp. 71-82.

THORNE, B.

1993 Gender Play: Girls and Boys in School, New Brunswick, New York, Rutgers University Press.

\section{TOREN, Christina}

1999 Mind, Materiality and History. Explorations in Fijian Ethnography, London/New York, Routledge.

TOREN, Christina

2002 "Anthropology as the Whole Science of What It Is to Be Human", in FOX, Richard; KING, G.; BARBARA, J. (eds.), Anthropology Beyond Culture, Oxford, Berg, pp. 105-24.

\section{WARTOFSKY}

1983 "The Child's Construction of the World and the World's Construction of the Child", in KESSEL, F. S. \& SIEGEL, A. (eds.), The Child and Other Cultural Invention, New York, Praeger.

WEISZ, John

1980 "Autonomony, Control, and Other Reasons Why Man Is the Greateast: a Content Analysis of Children's Mother's Day Letters", Child Development, 51, pp. 801-7. 
Flávia Pires. Ser adulta e pesquisar crianças...

ABSTRACT: The paper discusses methods and techniques of research used to study children from the perspective of anthropology. It is based on my own fieldwork experience, focuses on the relation between religion and children.

KEY-WORDS: children, childhood, drawings, participant observation, writings.

Recebido em maio de 2007, aceito em setembro de 2007. 